\title{
The End of Reurbanisation? \\ Phases of Concentration and Deconcentration in Migratory Movements in North Rhine-Westphalia
}

\author{
Frank Osterhage
}

\begin{abstract}
For some time now, there has been a lively debate about reurbanisation in Germany with regard to trends in spatial development. At the same time, the consequences of spatially imbalanced development can be observed in many regions. In large metropolitan areas in particular, the renewed appeal of cities has made living space scarce and expensive. There is extensive investment in residential construction and infrastructure, yet the first signs of a further shift in the trend are starting to emerge. It is against this background that this paper investigates migratory movements in the state of North Rhine-Westphalia, covering a period of more than four decades. The resulting change in the distance between place of residence and the nearest major centre is calculated for each case of migration in the time period under investigation. By aggregating the individual values, an indicator is generated that can be used to identify different phases of spatial concentration and deconcentration. The results remind us that for a long time the predominant forces in migratory movements were centrifugal. This makes the transition to the spatial concentration phase that took place in the past decade, and that can be precisely traced from the values obtained, all the more striking. In the final years of the period under investigation, the results are significantly influenced by the handling of the publicly-directed migration of refugees and asylum-seekers within the state. If municipalities with admission facilities for these groups that exhibit anomalous migration data are excluded from the analysis, deconcentration processes appear in fact to be gaining the upper hand again in North Rhine-Westphalia. Renewed momentum in residential suburbanisation in the areas surrounding the major centres is behind this current development. Deceleration of the migratory losses from more peripheral municipalities can also be observed, however.
\end{abstract}

Keywords: Reurbanisation · Suburbanisation · Internal migration · Trends in spatial development $\cdot$ North Rhine-Westphalia 


\section{Introduction}

As a rule, population development does not occur homogeneously in a region, a federal state or a country. Migratory movements in particular can result in differing developmental dynamics in different areas. These lead in turn to redistribution of the population as a whole and of individual population groups. Among other reasons, such trends are significant because they have an impact on the local demand for everyday goods and services. Hence, living space can become scarce and expensive in particularly popular destination regions, whereas falling prices and vacancies arise in regions experiencing emigration.

In the second half of the $20^{\text {th }}$ century in western Germany, and then following German reunification also in eastern Germany, spatial development was characterised by various stages of demographic deconcentration (Siedentop et al. 2003). Toward the middle of the past decade, however, a debate about a noticeable change in the trend began, which in subsequent years was demonstrated in a series of empirical studies. The positive migration balances and - comparatively - favourable population development in many cities and urban agglomerations led researchers to speak of a phase of reurbanisation (e.g. Brake/Herfert 2012; Herfert et al. 2010; Siedentop 2008). The rapid increase in the number of inhabitants in some places and the associated growth pressures gave rise to considerable policy and planning challenges with respect to the creation of new residential space or the adaptation of available infrastructure, for example. At the same time, there was increasingly intense discussion about possible depopulation and peripherisation of rural areas (e.g. Berlin-Institut für Bevölkerung und Entwicklung 2011). It remains an open question whether and how long this reurbanisation trend will persist. First indications have recently been found in the press that suggest a renewed tendency toward spatial deconcentration in population development (Kollenbroich et al. 2016; Ochs 2016).

The present article examines the phases of spatial concentration and deconcentration that have occurred in recent years. The analysis puts the focus on migratory movements, which represent numerous individual decisions for or against a place of residence. As a contribution to the debate about current trends in spatial development, the objective is to show changes over time as precisely as possible and, in doing so, to differentiate based on attributes such as the age and nationality of the persons who have migrated. The salient question of when it is appropriate to speak of an "end of reurbanisation" is also discussed. The study uses the example of North Rhine-Westphalia. With a population of around 17.9 million people (on 31/12/2015), North Rhine-Westphalia is Germany's most populous state by far. And even though 29 of Germany's 80 largest cities containing over 100,000 inhabitants are located in North Rhine-Westphalia, there are relatively few studies on the subject of "reurbanisation" for this state. The available data for North Rhine-Westphalia offers particular opportunities for analysing migratory movements and was also decisive in the choice of area to be studied.

The current state of research on internal migratory movements in Germany is presented at the beginning of this article. In the following section there is a discus- 
sion of the methodological approach, in which detailed information is given on the data basis used for the examination. The results of the data analysis are then presented with the aim of identifying different phases of spatial development in North Rhine-Westphalia. In the final section the findings are summarised and discussed in relation to the durability of the current reurbanisation trend.

\section{Current State of Research}

\section{Understanding of Reurbanisation}

In the search for a definition of reurbanisation, a large degree of uncertainty and a wide range of interpretations are encountered. A series of attempts has thus been made to impose a structure and to elaborate different dimensions of meaning (e.g. Brake/Urbanczyk 2012; Glatter/Siedhoff 2008; Bourne 1996). Many of these proposals distinguish between a normative and an analytical approach. The analyticallyoriented perspective can be sub-divided in turn into qualitatively and quantitativelyoriented approaches. The present paper belongs to the analytical-quantitative studies.

The aim of these studies is to observe reurbanisation empirically using statistical indicators. In most cases, population development is the object of observation, which is also supported by the availability of the required data. In part, however, the focus is on development in other domains such as employment or the retail trade. It should, moreover, be noted that differing measurement concepts are used in identifying and describing demographic reurbanisation processes, and this has considerable influence on the results presented (Osterhage 2011). The prominent phase model of urban development, which emerged in the context of a European study of cities at the beginning of the 1980s (van den Berg et al. 1982), is still an important point of reference. This model is used to establish the change in the population number in the core and the ring of a functional urban region in order to determine differing phases or stages of spatial development. Over the years, different variations of the original model have been developed and applied (Parr 2012). In many analytical-quantitative studies, overall population development is no longer the focus, but rather, with differing emphases, migratory movements (e.g. Rérat 2012; Sander 2014; Busch 2016). It is argued that the new growth of cities depends mainly on a surplus of in-migration and that the separate consideration of different migration types promises deeper insights into trends in spatial development.

\section{Spatial Migratory Patterns in Germany since the 1960 s}

In the 1960s, once the main reconstruction phase following the destruction of the Second World War had passed, migratory movements from the city centres to the surrounding outskirts were increasingly observed in West German metropolitan areas (Kemper 1999). In combination with the widespread desire to own property in a leafy neighbourhood, the triumphant rise of the private car as well as the expansion of public commuter transport led in the following years to a peak phase of residential 
suburbanisation (Häußermann et al. 2008: 85-89). In somewhat diminished form, this phase persisted into the 1980s in many regions (Bucher/Kocks 1987). Indeed, in the period between 1978 and 1984, there is evidence of inter-regional deconcentration in West Germany that led, by way of internal migration, to a population shift to less densely-populated areas (Voge/sang/Kontuly 1986; Kanarog/ou/Braun 1992). In the second half of the 1980s, however, a reversal of this trend became apparent. Concentration processes in favour of urban agglomerations took hold and some researchers speculated about the beginning of a reurbanisation phase (Kontuly/Schön 1994; Kemper 1999; Gans 2000).

The turbulent period of German reunification or "Wendezeit" (1989-1990) represented a special historical situation that had immense consequences for migration (Kemper 2003; Kontuly et al. 1997). Extensive migratory movements from East to West predominated, and this, in combination with the immigration of resettlers ("Aussiedler", i.e. descendants of German settlers in Eastern Europe), refugees and asylum-seekers, led to strong pressure on housing markets in western German metropolitan areas. In the 1990s, a veritable surge in suburbanisation could be observed in the "new states" of eastern Germany (Herfert 1998; Aring/Herfert 2001). Following reunification, massive public housebuilding subsidies along with the new possibilities of property ownership resulted in a construction boom in the surroundings of the eastern German core cities and hence in widespread intra-regional deconcentration. But a new peak phase of residential suburbanisation, which lasted into the second half of the decade, also occurred in the "old states" of western Germany. This phase was characterised by spatial expansion in some metropolitan areas (Schlömer 2004: 101-104) and an unprecedented variety of household types among the new suburbanites (Aring/Herfert 2001). In contrast to the situation in eastern Germany, rural areas recorded constant gains in internal migration in this period (Kemper 2003: 14-15; Böltken et al. 1997: 38). Toward the end of the decade, a weakening of the centrifugal forces became apparent amidst the migratory movements. This concerned both the suburbanisation processes (Herfert 1998: 774; Hallenberg 2002: 134-136) and the large-scale deconcentration (Mai/Schlömer 2007).

After the turn of the century, reurbanisation was discussed in migration analyses as a continuation of this development: initially with a certain degree of reserve (Köppen et al. 2007; Hirschle/Schürt 2008) and then, somewhat later, more assertively (Herfert/Osterhage 2012). As the outcome of a detailed study of internal migration, Sander (2014: 229) finds that the patterns of migratory gains and losses changed completely between 1995 and 2010. Overall, upward migration flows within the urban hierarchy have gained in importance. Thus, the proportion of people who move to other large cities has increased, whereas the number moving from cities to their surrounding areas has decreased. While there are considerable regional differences, the fact that the core regions are able to achieve high migratory gains while gains are decreasing or losses even being seen in many of the other regions outside the urban agglomerations is recognised as the overriding trend (Sander 2014: 233). Milbert and Sturm (2016), who undertook an analysis of migratory movements in Germany between 1975 and 2013, arrive at a very similar assessment. In their con- 
clusion, the authors prefer not to speak of a "rural exodus", but they point to the fact that emigration from rural areas to large cities has increased.

Recently, however, there have been signs that the trend toward spatial concentration is coming to an end. Busch (2016) finds that many large cities now exhibit a clearly negative migration balance from internal migratory movements - a development that is obscured by heavy immigration from abroad. He regards the main cause to be the fraught urban property market in many places, which leads to a process of displacement in favour of suburban and rural municipalities. However, he sees no signs of a general loss in the attractiveness of urban living (Busch 2016: 93-96). Similar shifts in the internal migration balance also emerge in the study conducted by Milbert (2017). She distinguishes between different groups of large cities and points to the fact that the migratory gains achieved by the cities began to decline in 2011, and in 2014, for the first time, almost fell back to zero again or were even negative. In her analysis of the causes she emphasises that higher rental and property prices alone cannot explain the renewed tendency toward intra-regional deconcentration (Milbert 2017: 14-16).

\section{A Life-Course Perspective on Migration}

Studies conducted on the basis of aggregated migration data have repeatedly shown that there are striking differences between age-groups with respect to the frequency and the predominant direction of migration. The needs, preferences and resources of individuals - and hence also of households - evidently change over the course of a life and this can cause people to move house and change their place of residence. These sorts of considerations led to the application of the sociological family-cycle concept to issues in migration research (Rossi 1955) - and later to the extension of this somewhat rigid model beyond the narrow focus on the nuclear family (e.g. Kemper 1985). Subsequently, numerous studies emerged that were conducted from the life-course perspective and that focussed on a systematic analysis of the connections between spatial mobility and biographical events (e.g. Wagner 1989; Kley 2011, 2009; Gerber 2011).

Typical age-specific patterns of internal migration in Germany emerge from people's many individual decisions about where to live, and they display a high degree of temporal stability. These patterns reveal that the educational migrant age-group, in particular, moves to cities, whereas family migrants, as well as senior migrants, tend to prefer the surrounding areas of the core cities, or more rural regions ( $B u-$ cher/Schlömer 2012: 70; Schlömer 2009: 115-122).

The predominant direction of migration in the different age-groups has not fundamentally changed in recent years. Nonetheless, a reurbanisation trend has come about as a result of level changes. Thus, Sander (2014) finds that there has been a further clear increase in moves to urban centres among young adults and, at the same time, moves out of the core cities have decreased among the 30- to 49-yearolds. In keeping with this, according to Milbert and Sturm (2016), the significance of emigration of educational migrants from rural areas to cities has increased. Like Simons and Weiden (2016), they also point to the fact that the orientation toward cities 
persists in the subsequent phase of starting a career and deciding on a profession. Instead of returning home, college graduates increasingly move on to other cities (Simons/Weiden 2016). Busch (2016), however, asserts that in the recent past the migratory gains of cities among young people have not been sufficient to compensate for the losses due to family migration, which are growing again in the context of a very competitive housing market.

\section{Migration and Nationality}

Overall, differentiation based on nationality has only played a subordinate role in the studies of internal migration within Germany that have been conducted in recent years. As an exception to this rule, Busch (2016) consciously treats the migratory movements of German nationals separately. As a result of this approach he determines that between 2008 and 2014 there was a transition toward suburbanisation among the group of non-foreigners and, in individual regions, even de-urbanisation (Busch 2016: 90-92).

Although the internal migratory movements of foreigners are not, as a rule, directly considered, there is a larger number of studies on the regional distribution of foreign nationals and/or people with immigration backgrounds (e.g. Gans/Sch/ömer 2014; Korcz/Schlömer 2008; Kemper 2006; BAMF 2016). The findings presented on this subject make two points clear: firstly, there are large differences among the various sub-groups comprising the immigrant population. Secondly, distinctive spatial patterns can be detected for many of these groups. In light of such findings, Korcz and Sch/ömer rightly speak of a "systematicity amidst the diversity" (2008: 165). Keeping in mind the existing specificities, it can be said that immigrants are concentrated in urban agglomerations in the western part of Germany (Worbs et al. 2005: 44). Hence, it is not surprising that immigrants - in particular, those with limited income - are mentioned as a central pillar of the current reurbanisation trend (Kabisch et al. 2012: 122-123; Haase et al. 2010). The great significance of social networks and the importance of access to rental markets for many people with immigrant backgrounds are cited as causes of this pronounced affinity with cities (Gans/Sch/ömer 2014).

Alongside the direct inflow from other countries and the natural development of the population, the precise contribution of internal migration to the emergence of the existing patterns of distribution is, however, largely unclear. The complex inter-connections between external migration and related internal migration, which have hitherto rarely been the subject of systematic study, need also to be taken into account here (Korcz/Sch/ömer 2008: 168). This includes the numerous special cases of publicly directed migratory movements of groups like asylum-seekers, refugees and (late) resettlers (Sch/ömer 2012: 50-51; Worbs et al. 2005: 45). 


\section{Data Basis and Methodological Approach}

In the reurbanisation debate of recent years, various approaches have been employed in order to identify different phases of spatial development. This paper is based on the analysis of migration data and hence looks at active changes in the place of residence. This approach is distinguished by the fact that all cases of migration within the geographical area of a federal state are included in the statistical analysis. Based on this indicator, a phase of reurbanisation can be identified in which spatial concentration, i.e. a shift towards the existing major centres, is present in the migratory movements.

\section{Measurement of Concentration and Deconcentration}

The subject of this paper is migration within North Rhine-Westphalia and the trends in spatial development that accompany it. All cases of migration that extend beyond the boundaries of a municipality and where the municipality of origin as well as the municipality of destination are within the state boundaries of North RhineWestphalia were considered for the period from 1975 to 2015. Data from the migration statistics served as the basis for the analysis. The migration statistics represent an exhaustive data collection that is based on the registrations recorded by the municipal registration offices. Moves within a municipality are not included in the migration statistics. The statistics contain the old and new place of residence, but also other attributes like the age and nationality of the person who has migrated. The Federal Statistical Office rates the quality of the data as good (Statistisches Bundesamt 2017: 7-8).

The available migration data was used to identify phases of spatial concentration and deconcentration, and a significant indicator of spatial development was created as a result. The value yielded by this indicator was meant to reveal whether the migratory movements in North Rhine-Westphalia are more directed toward the existing centres or rather toward the inner and outer fringes of the state territory. Thus, the distance to the nearest major centre of the old and new places of residence was determined using a geo-information system for each case of migration. How this distance, and hence the proximity to a major centre, changed as a result of the migratory movement could then be calculated. The straight-line distance ("as the crow flies") between the middle points of both of the municipalities in question was used for the measurement. All cities that are classified in the "Oberzentrum" category by the federal state planning authority, and thus fulfil important regional functions, were defined as major centres.

The resulting particularity of the analysis can best be illustrated using the example of a move from a domicile on the periphery of the state of North Rhine-Westphalia to the neighbouring municipality of a city with the status of major centre. Although this move is not to the major centre itself, in the approach described it is considered as a case of migration that decreases the distance to the nearest major centre and thereby contributes to spatial concentration. 


\section{Study Area and Transferability of the Findings}

Two points were decisive for the choice of area to be studied. Firstly, a data basis is available for North Rhine-Westphalia that facilitates special analysis of migration data and that is not available for any other German state. Secondly, various reasons relating to the size of North Rhine-Westphalia and the diversity of its regions favour this choice. Thus, not only local migrations can be taken into account, but also migrations over intermediate and longer distances thanks to the expanse of the state territory. In addition, the differences between regions, cities and villages ensure coverage of a large range of migration types and associated motives for migration. Finally, North Rhine-Westphalia is Germany's largest state by far in terms of population size, and comprises a significant proportion of all migratory movements in the country as a whole.

The data used from the migration statistics was made available by the Information und Technik Nordrhein-Westfalen (IT.NRW) state agency, which acts as the statistical office of the federal state of North Rhine-Westphalia. The data available from IT.NRW is characterised by certain particularities that make a study of North RhineWestphalia especially interesting. Principal among these is the exceptionally long period of available reporting years. This period goes back to 1975 , which makes statistical analyses covering more than four decades possible. In contrast, comparable data for the whole national territory made available by the Research Data Centres (RDC) of the Federal Statistical Office and the regional Statistical Offices of the federal states only starts in 2000. It should be emphasised, moreover, that IT.NRW publishes complete data sets with two-dimensional migration data covering movements between all the municipalities in the state of North Rhine-Westphalia. This makes complex analyses possible on a very localised level without information being lost due to data aggregation in the provision of the data. The agency also refrains from blocking weakly-occupied cells for reasons of confidentiality.

The settlement structure and system of centres in North Rhine-Westphalia exhibit certain peculiarities that are of significance for this study. The core area of the state - along the Rhine and in the Ruhr region - has been strongly marked by far-reaching processes of urbanisation. In these areas of high population density, many cities are found in close proximity to each other. In addition, there are several "freestanding" centres like Münster, Bielefeld, Paderborn, Siegen, and Aachen. At the same time, it should be noted that there are also some less densely populated areas, mainly on the periphery of North Rhine-Westphalia. The central place concept ("Zentrale-Orte-Konzept") that was established at the end of the 1970s in the state development plan (Der Ministerpräsident des Landes Nordrhein-Westfalen 1979) and that still applies unchanged today, classifies 16 cities across the state as major centres (Fig. 1). Centres in the neighbouring states of Lower Saxony, Hesse and Rhineland-Palatinate were also taken into account in determining the distance to the nearest major centre. The shortest distance in the case of a few municipalities is indeed to the major centres of Hannover or Osnabrück in Lower Saxony. Centres in the neighbouring countries of Belgium and the Netherlands, on the other hand, were not taken into consideration. Available studies clearly show that interconnec- 
Fig. 1: Distances of municipalities in North Rhine-Westphalia to the nearest major centre

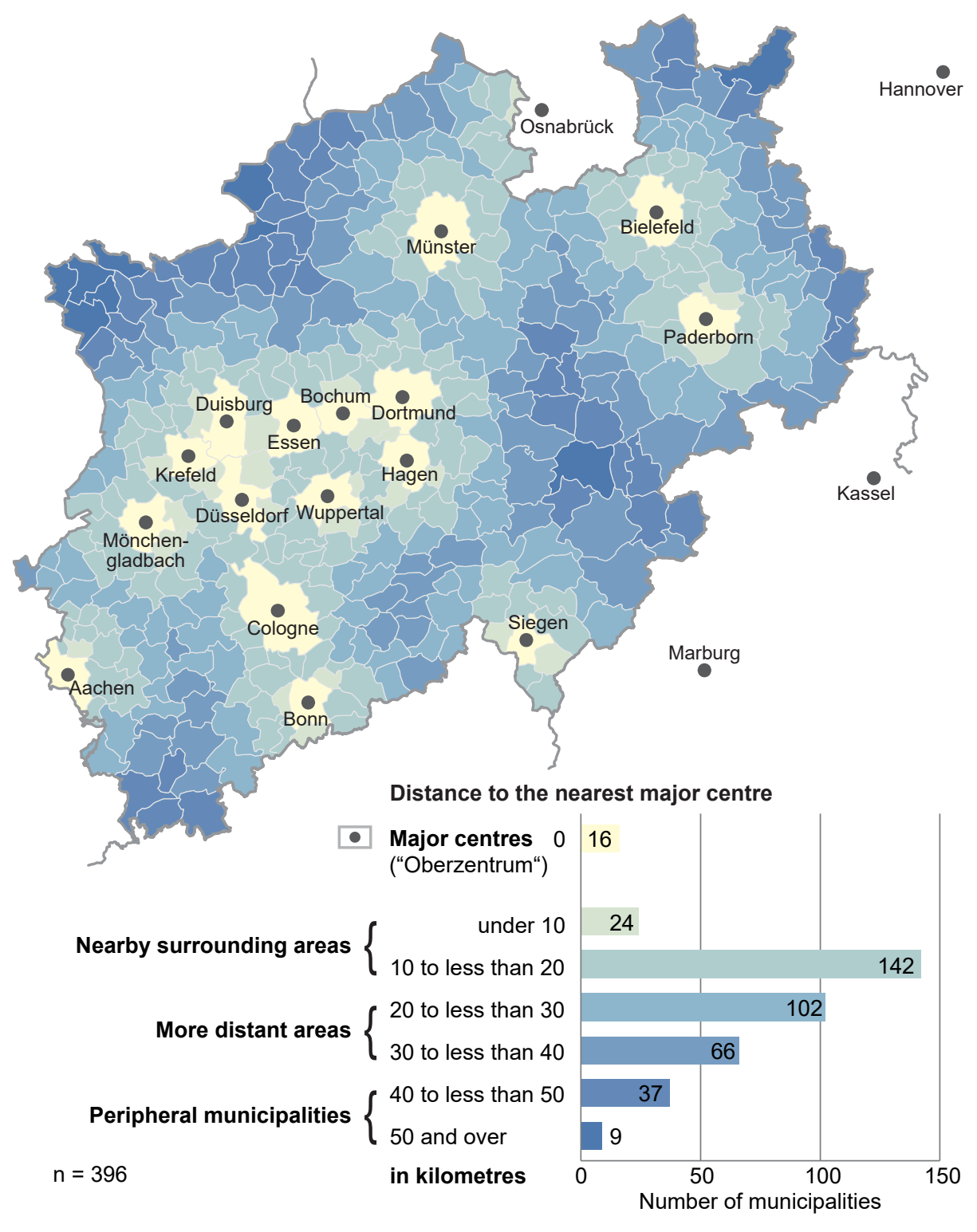

Source: own calculations

tions that transcend national borders are still relatively weakly developed (Münter) Osterhage 2017). The calculations show that the straight-line distance to the nearest major centre is less than 20 kilometres for 46 percent of all municipalities in 
North Rhine-Westphalia; for nine out of ten localities, the distance remains under the threshold of 40 kilometres. The greatest distances, of over 40 kilometres, are for some municipalities in Ostwestfalen-Lippe, in the Sauerland and on the Lower Rhine.

With respect to the transferability of the study findings to the situation and development in Germany as a whole, the size of North Rhine-Westphalia and the diversity of its regions should again be emphasised. This ensures that many different cases of migration are included in the study, lending the results a high degree of robustness. Nonetheless, the well-founded reservations regarding generalising findings from case studies in spatial-scientific research apply to a certain extent. This is particularly the case for the transferability to spaces that are unique and clearly diverge from the conditions in North Rhine-Westphalia with regard to features like the number and accessibility of major centres, the settlement structure or the housing and property markets. Examples include study areas that are more rural in character or display a pronounced monocentric settlement structure.

\section{Identification of Outliers}

A major challenge involved in considering internal migration lies in the treatment of publicly-directed movements of people who previously immigrated from abroad. After entering Germany, groups like asylum-seekers, refugees and (late) resettlers are first sent to places with central admission facilities. Then, in a second step, the new arrivals are distributed to the other municipalities in North Rhine-Westphalia and these publicly-directed movements are registered as internal migration. But since the actual starting point for the migratory process is outside the area under consideration, the treatment as internal migration can be regarded as an artefact of the registration system and hence of the migration statistics. Furthermore, due to the fact that the persons migrating have no free choice, they are only comparable to other migratory movements to a limited extent. Consequently, there are good substantive arguments for not taking into account this form of migration in analysing migratory movements, or for treating it separately. The statistics, however, do not permit the clear recognition of cases of migration that have been influenced by public measures or their direct exclusion. Instead, municipalities, where central admission facilities are located, are entirely excluded from analyses on internal migration in most studies.

But this approach also carries certain difficulties. The number and locations of these facilities do not remain constant over time, and are sometimes subject to considerable change. Particularly in phases of high immigration, numerous larger and smaller facilities are in operation, making it retrospectively very difficult to determine which facilities were used, how intensively, and at what point in time. Apart from this information deficit, it should also be borne in mind that complete exclusion of all the municipalities in question will inevitably result in many non-publicly-directed migratory movements also being excluded from the analysis. For this reason, it is indeed questionable whether such filtering does in fact lead to better interpretability of the research findings (Schlömer 2009: 32). 
After the advantages and disadvantages had been weighed up, particularly anomalous migration data was excluded at the municipality-level. In a first step, outflow rates (number of departures per 1,000 inhabitants) were calculated for all municipalities in the state of North Rhine-Westphalia as the basis for identifying outliers. In terms of internal migratory movements, municipalities containing actively used admission facilities generally have a conspicuously high number of people who have moved away. Outflow rates were determined separately based on nationality (Germans and foreign nationals) for the 41 reporting years in the period under investigation. In a second step, appropriate threshold values were established for the classification of outliers. Here it proved useful first to sub-divide the dataset into three groups based on municipality size (fewer than 20,000 inhabitants, 20,000 to less than 100,000 inhabitants, 100,000 and more inhabitants). The median of the outflow rates for the individual groups was then found in order to serve as a point of departure for determining the threshold values. If the outflow rate of a municipality was a multiple of this average value, it was classified as an outlier, and both the moves away from and the moves to the municipality in question were excluded from the data set. At the same time, intensive documentary research was conducted in order to obtain a detailed overview of the admission facilities in North RhineWestphalia over the last four decades. The results of this research were used to validate the threshold values from the statistical derivation and to determine the multipliers that were finally used.

\section{The Influence of Publicly-Directed Migratory Movements}

For the greater part of the period under investigation, just a few municipalities were excluded from the analysis. These are municipalities that are known to have served for many years as the location of a large admission facility (e.g. Unna, Schöppingen and Hemer). In contrast, the reporting year 2015 has an exceptional status. After checking the migration data for 2015, a total of 16 municipalities were classified as outliers - by far the highest number of all years under consideration. A sharp increase in the number of immigrating refugees and asylum-seekers created a need to expand the existing capacities in North Rhine-Westphalia to provide accommodation for the newly arrived people (Ministerium für Inneres und Kommunales des Landes Nordrhein-Westfalen 2016).

Publicly-directed migratory movements can considerably influence the patterns of internal migration. Despite the moderate number of outlier municipalities, the excluded migration cases are remarkably large in some years (Fig. 2). Around 98,000 migration cases of people with foreign nationality were excluded in 2015 , which corresponds to almost 15 percent of all internal migrations in North RhineWestphalia. During the period from 1988 to 1990 the number of excluded migration cases was similarly high. The causes of this can be traced back to the city of Unna, which was the location of a central state facility for resettlers, immigrants and foreign refugees at that time and registered an extremely high number of outflows to other municipalities in North Rhine-Westphalia. 
Fig. 2: Publicly-directed migratory movements: number of excluded migration cases 1975-2015

Number of excluded migration cases

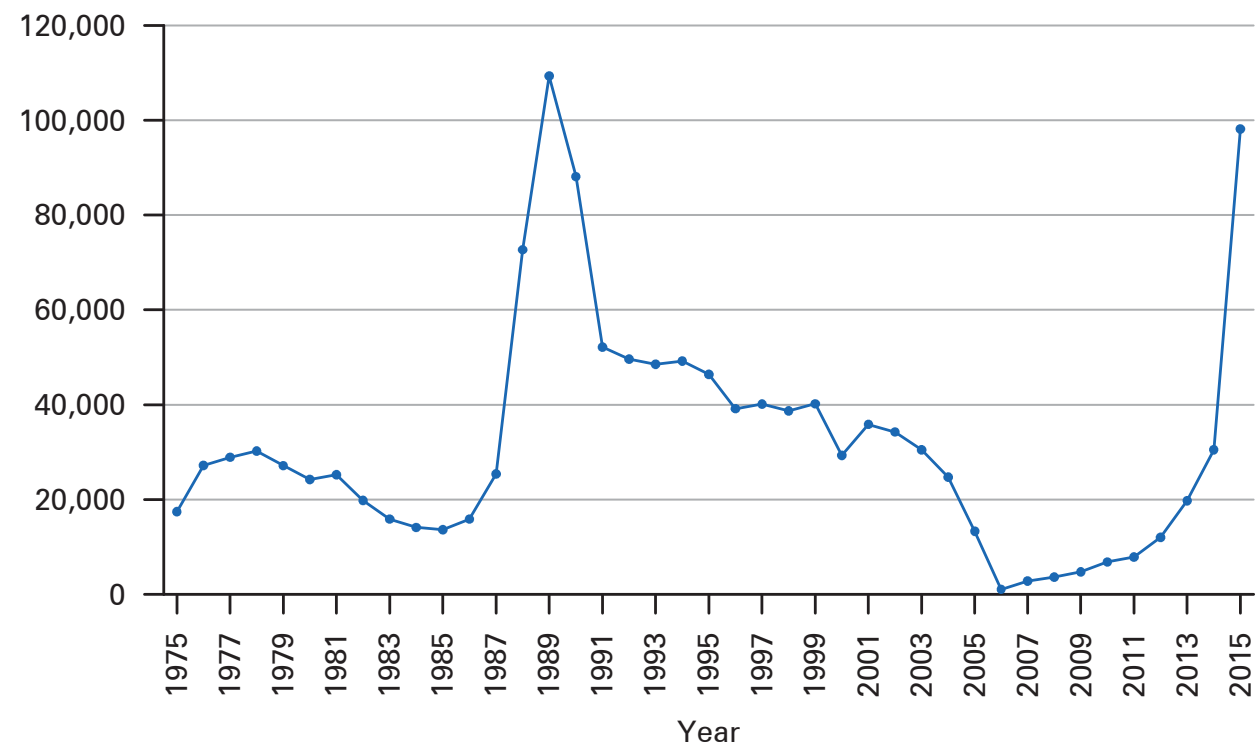

Source: own calculations based on Information and Technik Nordrhein-Westfalen (IT.NRW) Wanderungsstatistik

Bearing in mind the objective of the data analysis, it is important to realise that the admission facilities are not evenly distributed over the state territory. The outlier municipalities tend to be of medium or small size and to be of above-average distance to a major centre. As a consequence, the influence of publicly-directed migration on migratory movements in North Rhine-Westphalia favours spatial concentration. Such effects can be substantial in years of high immigration. Indeed, in the late 1980s the inclusion or exclusion of migration cases determined whether the indicator values were positive or negative.

\section{$4 \quad$ Presentation of the Findings}

The focus of this paper is the extent to which different phases of concentration and deconcentration can be identified for North Rhine-Westphalia in the recent and more distant past on the basis of migratory movement data. Before going into the results of the data analysis, the relevance of internal migratory movements during the investigation period (1975-2015) is examined (Fig. 3). In the period under consideration, the number of statistically recorded cases of migration within the state was around 532,000 persons per year on average. For comparison's sake, Figure 3 also includes the numbers of inflows from other parts of Germany and from abroad 
Fig. 3: $\quad$ Migratory movements within NRW, inflows from other parts of Germany to NRW, and inflows from abroad to NRW 1975-2015

Number of migration cases

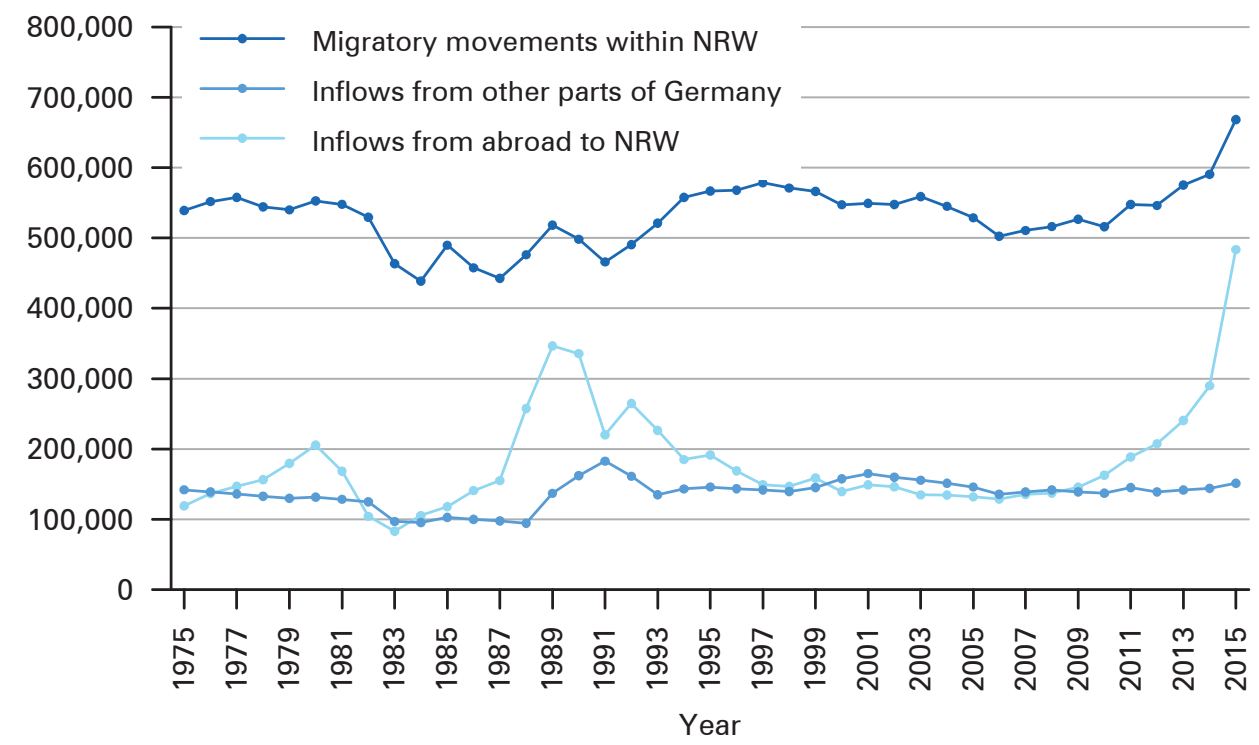

Source: own calculations based on Information and Technik Nordrhein-Westfalen (IT. NRW) - Landesdatenbank NRW

- and hence for all other migratory movements with destinations in North RhineWestphalia. Over the entire period of the investigation, the volumes of the inflows from other parts of Germany and from abroad turn out to be considerably lower, thereby underscoring the quantitative significance of internal migration.

With respect to the evolution of the volume of migration, it is not possible to identify a continuous trend toward more or less internal migration in the period under investigation. However, appreciable fluctuations in the number of migratory movements occurred again and again. The clear increase of migratory movements within North Rhine-Westphalia at the end of the period under investigation, beginning in 2013 at the latest, is particularly striking. What stands out here is that there was a sharp increase in inflows from abroad at roughly the same time. Indeed, there are frequent references in the literature to the connections between international migratory movements and internal migration (e.g. Kemper 2003; Schlömer 2012).

\subsection{Phases of Concentration and Deconcentation}

After establishing the significance and influence of publicly-directed migratory movements in the methodology section, the subsequent presentation of the findings focuses on the calculations without the municipalities that have been classified as outliers. For each reporting year in the period under investigation, Figure 4 highlights how the internal migration changed the distance between place of residence 
Fig. 4: Average change in distance to the nearest major centre between old and new place of residence: all migratory movements within NRW without outliers 1975-2015

Kilometres

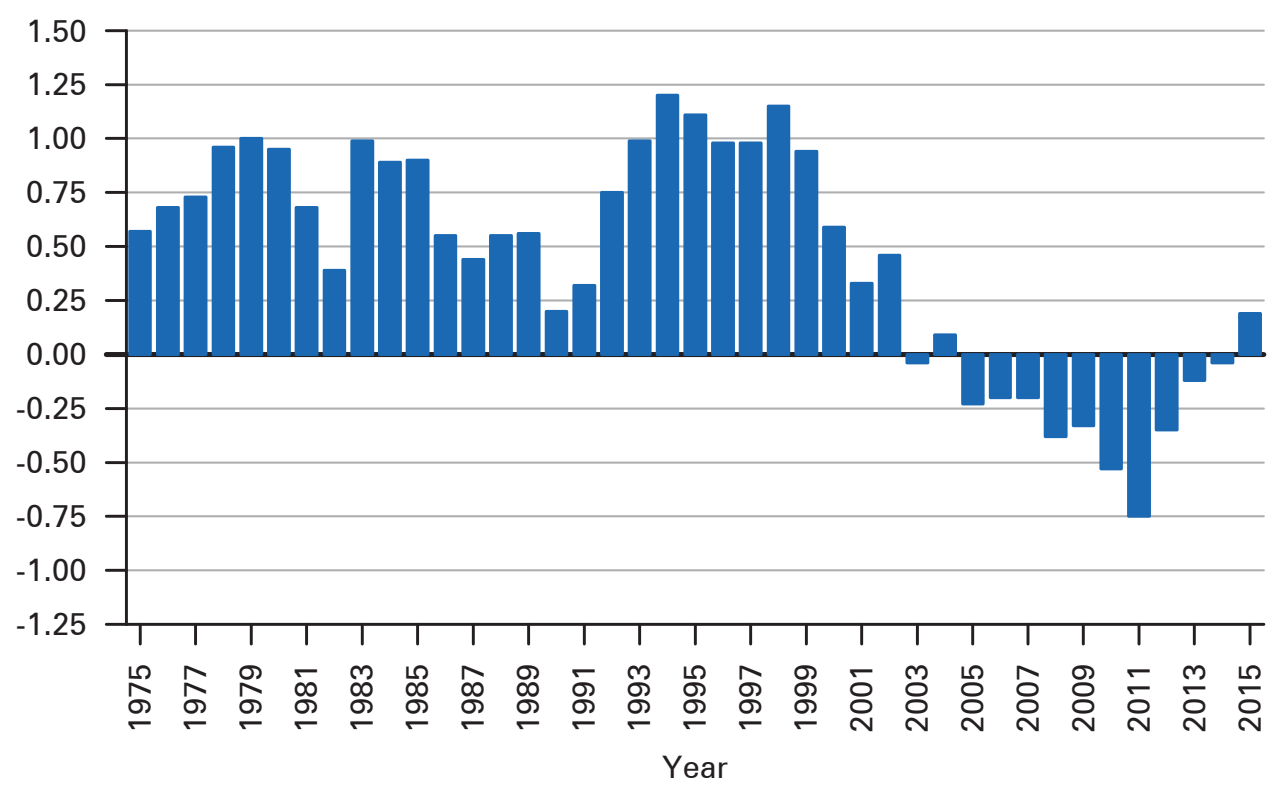

Source: own calculations based on Information and Technik Nordrhein-Westfalen (IT. NRW) - Wanderungsstatistik

and the nearest major centre. The values are calculated averages, since the sum of all the changes-in-distance has been placed in relation to the total number of internal migratory movements that took place in a given year.

The bar chart makes strikingly clear that centrifugal forces were for a long time the predominant migratory movement in North Rhine-Westphalia. During the period under investigation, there was uninterrupted spatial deconcentration up to and into the new century, which is expressed by values that lie clearly above the zero line. Despite fluctuations between the individual values, three different phases can be identified: Up until the middle of the 1980s, deconcentration processes remained at a relatively high level; they were then clearly attenuated for a few years, before new record levels were reached during the course of the 1990s.

For the first time since the start of the period under investigation, however, 2005 sees the start of a longer time segment in which overall migratory movements are more strongly directed toward the major centres. According to the measurement system used in this paper, this can be regarded as a phase of reurbanisation. Based on the values obtained, the spatial concentration is most pronounced in 2011. The distance between place of residence and the nearest major centre was reduced, on average, by 0.75 kilometres per case of migration in this year. Such a value is certainly significant bearing in mind that the phenomenon of migration generally 
comprises a large number of individual movements in different directions. What are initially seemingly inconspicuous imbalances can, over a longer stretch of time, bring about considerable changes in the spatial structure. With respect to current debates, it is particularly interesting to note that the concentration processes have continually weakened again in recent years - and in 2015 the values even switched over to increasing distances.

\subsection{Findings for Different Age-Groups}

The data basis of IT.NRW that was used in this study distinguishes between six different age-groups. The divisions are based on life-cycle phases that are often employed in analyses of migration data in this or similar forms (e.g. Sch/ömer 2009): family migration of children and adolescents ( 0 to less than 18 years old), educational migration (18 to less than 25 years old), career-start migration ( 25 to less than 30 years old), family migration of adults (30 to less than 50 years old), early phase of senior migration ( 50 to less than 65 years old), and late phase of senior migration (65 years old and more).

The calculated values vary greatly for the different age-groups (Fig. 5). This is in keeping with the findings of other studies on life-cycle migration. On the one hand, there is a tendency toward spatial deconcentration among the family migration groups (both age-groups) and the senior migrants (early and late phase) over the whole period under investigation. In contrast, the educational migration pattern is characterised by a pronounced tendency toward concentration. A change in the prevailing direction of migration can only be observed for one age-group, namely the 25 to less than 30 years olds: at the beginning of the period under investigation, the distances to the nearest major centre were still increasing for career-start migration. This remained the case until the second half of the 1990s, when a tendency to spatial concentration emerged. This tendency strengthened over many years and persists to this day.

The variation in the intensity of the concentration and deconcentration processes in the case of the other age-groups is, however, also instructive. It is thus striking that although the orientation of educational migrants toward the centres was already pronounced, there was a further considerable increase after the turn of the century. In addition, as has often been emphasised in the literature, the temporary weakening of the centrifugal forces at work in family migration contributed to the reurbanisation trend that appeared in the last decade. This development was even more pronounced in the case of senior migrants. In the "65 years and older" group, the average distances to the nearest major centre are still growing more than in any other age-group. At the same time, however, this increase in distance has diminished to a particularly notable extent over the course of the last two decades. It is also surprising that the values for the entire period under investigation have changed the most for persons aged between 50 and less than 65 years. According to the calculations, the migration-related increase in distances has diminished for this age-group from decade to decade. 
Fig. 5: Average change in distance to the nearest major centre between old and new place of residence: results by age group 1975-2015

0 to less than 18 years

Kilometres

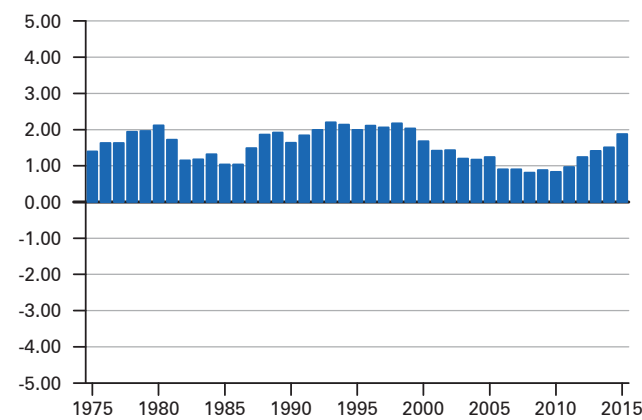

Year

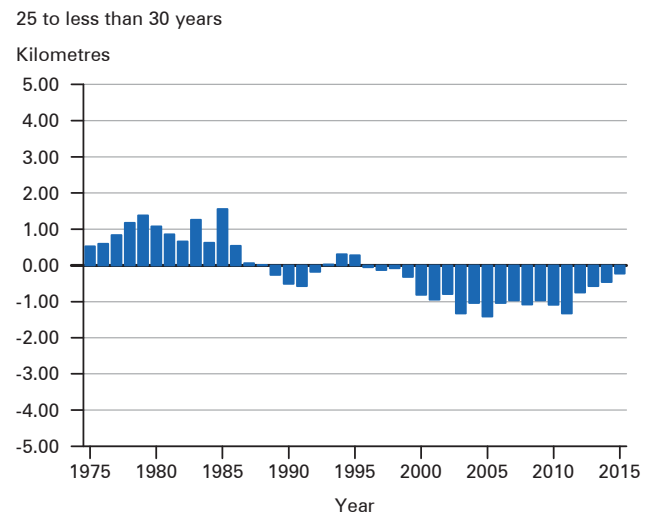

50 to less than 65 years

Kilometres

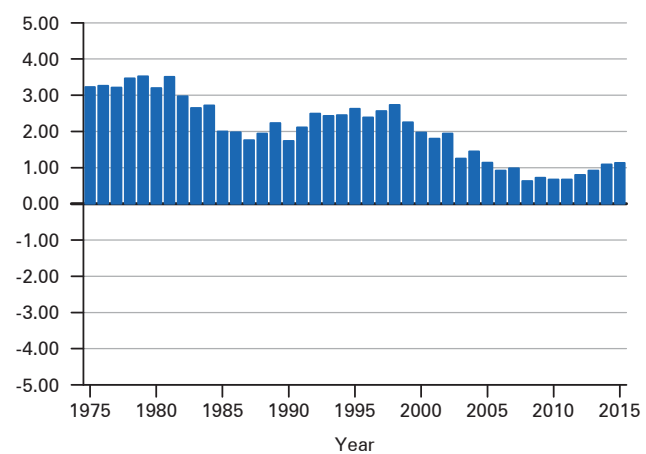

18 to less than 25 years

Kilometres

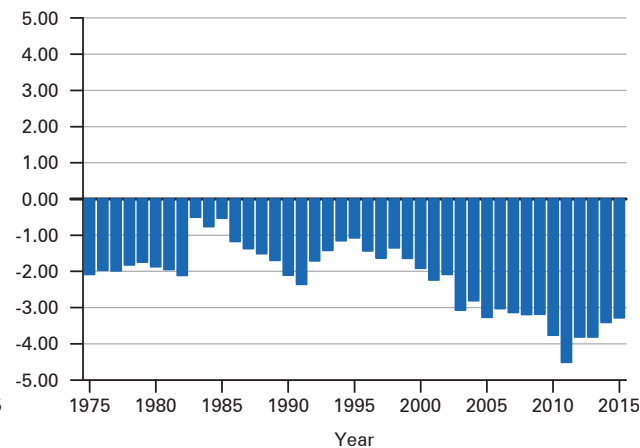

30 to less than 50 years

Kilometres

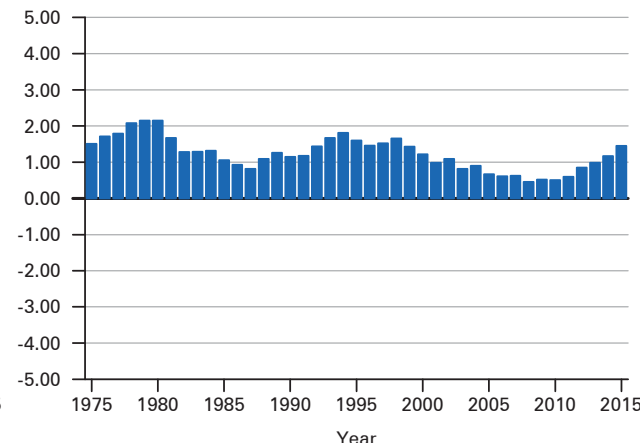

65 years and older

Kilometres

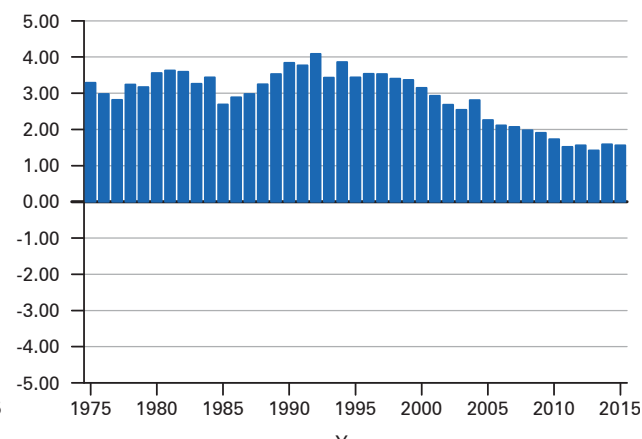

Source: own calculations based on Information and Technik Nordrhein-Westfalen (IT. NRW) - Wanderungsstatistik 
Concerning a possible end of reurbanisation, the detailed analysis allows us to ascertain that, in the case of most of the age-groups, at least a temporary peak of this trend has evidently been passed. In both of the family migration age-groups, there has been a strong return to outward migratory movements, and the indicator values are now at unprecedented levels in the new century. Furthermore, the orientation of the career-starters toward the major centres has also noticeably decreased since 2012.

\subsection{Findings for Germans and Foreigners}

The data made available by IT.NRW from the migration statistics allows for differentiation by nationality, whereby the two categories identified are "Germans" and "Foreign nationals". This differentiation is interesting because various publications presume that immigrants from abroad tend to move to western German urban agglomerations or to the larger cities as soon as they can freely decide their place of residence (Worbs et al. 2005: 44; Berlin-Institut für Bevölkerung und Entwicklung 2016: 65).

When analysed separately, it is in fact apparent that the values for people with German and foreign nationality differ considerably (Fig. 6). The tendency toward spatial concentration in migratory movements is clearly not a new phenomenon for the "foreign nationals" group. Since the beginning of the period under investigation, the calculated values have, for the most part, been negative, which signifies a migration-related reduction of the distance to the nearest major centre. The result for all the reporting years in the period under consideration is an average value of -0.33 kilometres per case of migration. This confirms the existing suppositions in the literature regarding a central orientation in the internal migratory movements of foreigners. On closer inspection, however, it is also notable that the centripetal forces have been continually losing their dominance since 2005. This observation could potentially be interpreted as convergence of the migratory behaviour among foreigners and Germans. In light of the extensive exclusion of outliers from the data set at the end of the period under investigation, such conclusions are, however, to be treated with some caution.

Over many years, there are large differences in the picture of the migratory movements of Germans. Up until the middle of the last decade, centrifugal forces predominated for this group without exception. For the first time in the period under consideration, a phase of spatial concentration is then to be observed from 2005 to 2013. Nonetheless, during the 41-year-long period under investigation, the distance to the nearest major centre increased on average by 0.54 kilometres with each move for German internal migrants. 
Fig. 6: Average change in distance to the nearest major centre between old and new place of residence: results by nationality $1975-2015$

Kilometres

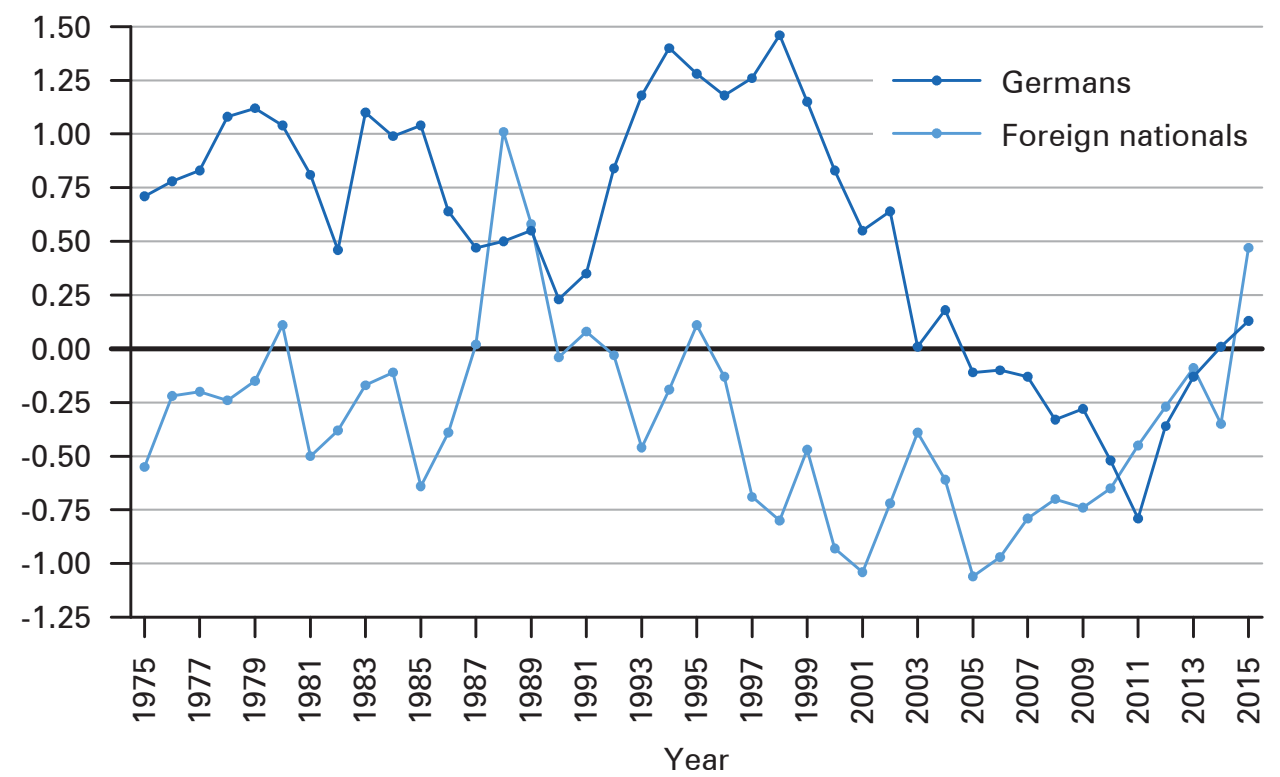

Source: own calculations based on Information and Technik Nordrhein-Westfalen (IT. NRW) - Wanderungsstatistik

\subsection{Migratory Movements between Different Territorial Categories}

In order to better understand the concentration and deconcentration processes behind the indicator values, the last part of the data analysis considers the migration flows between different territorial categories in North Rhine-Westphalia. Building on the previous analytical steps, the examination is based on four types of municipalities with different distances to the nearest major centre. The major centres themselves constitute the first category. The second and third types comprise municipalities in the nearby or more distant surroundings: at distances of less than 20 kilometres for category two and from 20 to less than 40 kilometres for category three. The fourth group consists of municipalities on the inner or outer periphery of the state that are located 40 or more kilometres from the nearest major centre.

Figure 7 shows how the migration balances between these territorial categories have changed over the years. The reporting years 1994, 2011 and 2015 were chosen for the purposes of the presentation, bearing in mind the results discussed so far. They constitute distinctive high points in spatial concentration or deconcentration phases that were identified in the data analysis. Migratory movements in 1994 are characterised by extensive deconcentration processes that affected all the relations between the types of municipalities. In particular, larger migration losses vis-à-vis the next less centrally-located territorial category emerged in a cascade-like pat- 
Fig. 7: Spatial patterns of migration between different territorial categories in North Rhine-Westphalia 1994, 2011 and 2015
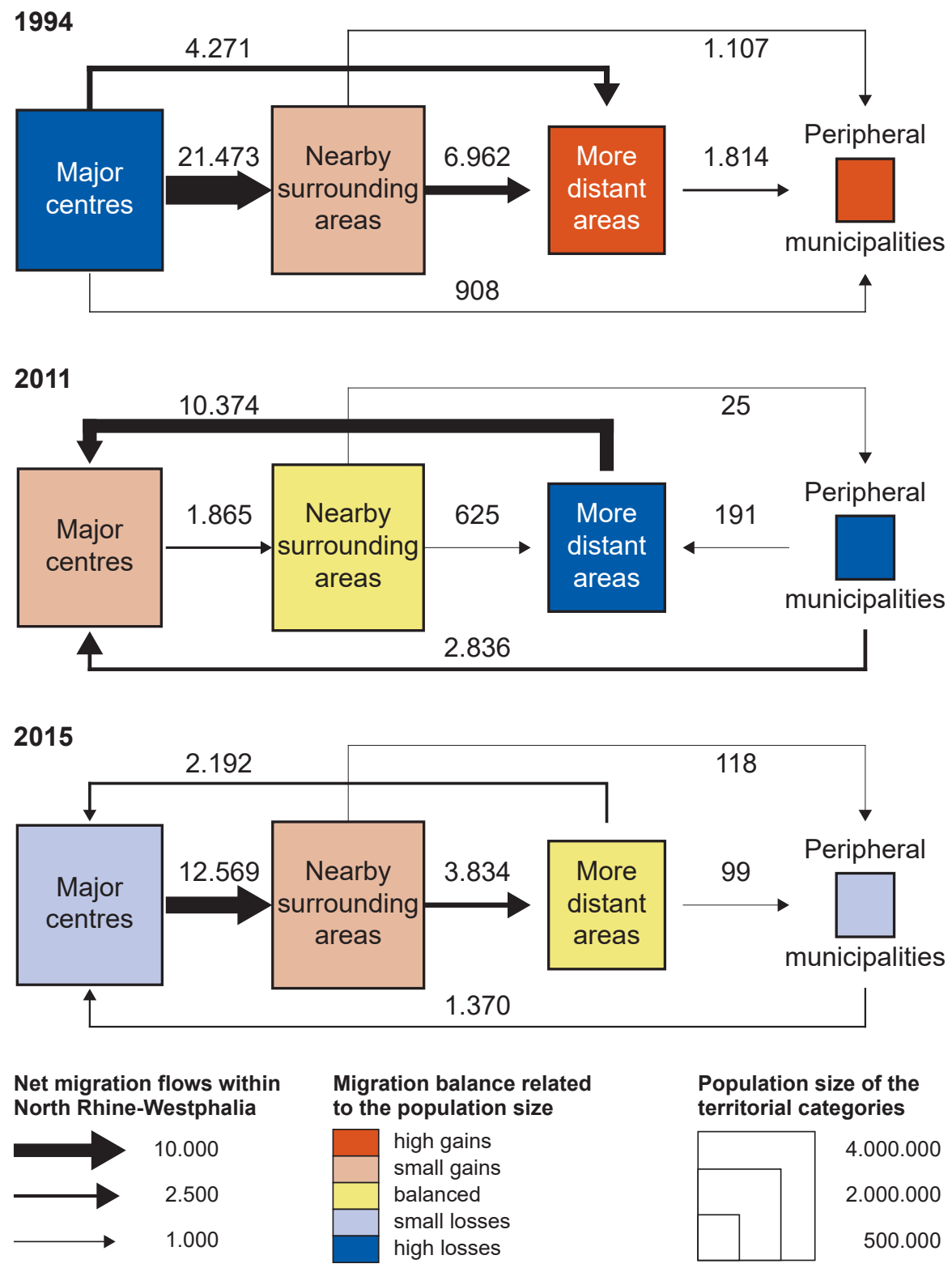

Source: own calculations based on Information and Technik Nordrhein-Westfalen (IT. NRW) - Wanderungsstatistik und Landesdatenbank NRW 
tern. In this sense, the substantial losses of the major centres in favour of the municipalities in the nearby surrounding area are striking. But the intensity of emigration to the more peripherally-located areas from the other categories is also notable.

Overall, there is a less one-sided pattern of migration in 2011, which represents the peak year of the recent reurbanisation phase. The analysis of the migration flows makes clear that the spatial concentration in this phase is predominantly the result of extensive migratory gains by the major centres at the expense of municipalities in the more distant surrounding areas or on the margins of North Rhine-Westphalia. At the same time, there are ongoing migration losses in favour of surrounding municipalities in the immediate vicinity of the centres - albeit at a comparatively low level.

Just a short time later, in 2015, the balances between the different territorial categories have again changed considerably. Residential suburbanisation has clearly increased, with stronger migratory movements from the major centres to the nearby surroundings observable. It can be assumed that the main reason behind this shift is the increasingly tense situation on the housing markets in many core cities - and not diminishing interest in urban living. Furthermore, the migration gains of the major centres at the expense of the other parts of the state have also weakened, which can be interpreted as normalisation of the spatial migration patterns. Overall, the municipalities in the "nearby surrounding area" category exhibit the most favourable internal migration balance in 2015.

\section{$5 \quad$ Conclusion and Discussion}

The study presented in this paper is based on the idea of determining the change in distance to the nearest major centre that results from migratory movements, and developing an indicator of spatial development trends from this. Based on the indicator values, it is possible to identify different phases of spatial concentration and deconcentration. In light of the current state of research, the findings can be regarded as plausible and instructive.

Thus, the phenomenon of reurbanisation, which has been intensively discussed in recent years, is also clearly apparent in the migratory movements in North RhineWestphalia. Between 2005 and 2014, there was a persistent tendency toward spatial concentration, which was unique in the more than four decades under investigation. Moreover, this phase of concentration is also manifest if only German nationals are included in the analysis. Based on the measurement approach employed here, which is deliberately directed only toward internal state migration, the reurbanisation trend was most pronounced in 2011. Weakening of the spatial concentration then followed for several years in a row until 2015 when the centrifugal forces among the migratory movements came to predominate again. In the case of certain subgroups - such as both family migration age-groups - the renewed shift in the trend began even earlier. Further analysis reveals migratory losses from the major centres in favour of the nearby surroundings and shows that the current development goes hand-in-hand with strengthening residential suburbanisation. It can also 
be observed that the migratory gains of the major centres vis-à-vis the more peripherally-located regions have recently resumed at a lower level.

The treatment of publicly-directed migratory movements - such as the accommodation in North Rhine-Westphalia of refugees and asylum-seekers who have recently immigrated from abroad - is of great significance for the results of the investigation at the end of the period under consideration. More specifically, the renewed shift toward spatial deconcentration is only apparent if the particularly anomalous migration statistics for certain municipalities are excluded from the data analysis. Nonetheless, in light of the numbers presented here, it is clear that the (temporary) peak of the reurbanisation phase has already passed and that the relative importance of the forces in migratory movements has shifted noticeably in recent years.

Considering the complexity of migratory movements and of the population development as a whole, the simultaneity of processes of reurbanisation and suburbanisation - of spatial concentration and deconcentration - has been repeatedly underscored in the literature (e.g. Milbert 2017; Hesse 2010; Hirschle/Schürt 2008). This is already correct due to the simple fact that migration balances as well as other aggregate indices are composed of a large number of migratory movements in different directions. In addition, there are considerable differences in migratory behaviour and the resulting spatial development trends if individual population groups or areas of investigation are considered. This became apparent in the present study when the results were differentiated by age-group or by nationality. Nonetheless, based on an overview of all migratory movements, the "change in distance from major centre per case of migration" indicator provides a reliable gauge of the extent to which centrifugal or centripetal forces predominate in migration flows in a given area at a given time.

Finally, is it now possible - to return to the title of this paper - to speak of the "end of reurbanisation"? Recently, the tendency in migratory movements in North Rhine-Westphalia has in fact shifted again towards spatial deconcentration. It can be shown that the overall NRW-wide internal migratory movements are no longer contributing to a reurbanisation trend. To assess this finding correctly, various points have to be kept in mind. The indicator used allows us to include all migratory movements within the boundaries of the state and to summarise the spatial orientation of those migrating in a single value. However, migration over the borders of North Rhine-Westphalia or of Germany is not considered. The recent preponderance of centrifugal forces thus applies only to internal migrations within the state and will probably be relativised if other migratory movements are taken into account. Worthy of particular mention here are the high number of inflows from abroad that have substantially influenced migratory movements in recent years. In addition, it is important to reiterate that this is an analytical-quantitative study involving a specific investigative approach. This approach has been chosen in the awareness that the rich debate concerning reurbanisation also includes many other facets.

In conclusion, it can be noted that the analysis of migratory movements provides informative findings for the study of trends in spatial development and the phenomenon of reurbanisation. There are three main aspects that should constitute essential elements of further research in this field: 
- Firstly, giving greater attention to different types of migration (local migration, long-distance migration, international migration) and how they interact promotes our understanding of demographic development. It is thus worthwhile exploring changes over time in detail and thereby revealing the backgrounds to shifts in population development trends.

- Secondly, city region case studies represent important building blocks of migration research. Closer understanding of the causal interrelationships can be derived by placing the observable migratory movements in relation to local conditions. This is particularly the case when the study design calls for comparison between different regions.

- Thirdly, the analysis of migration data should be supplemented by surveys of migrated households. Regular trend or panel studies hold especially great potential here. They would permit us to draw conclusions about possible changes in the motives for migration, which in turn would promise deeper insights into the causes behind the spatial development trends.

\section{References}

Aring, Jürgen; Herfert, Günter 2001: Neue Muster der Wohnsuburbanisierung. In: Brake, Klaus; Dangschat, Jens S.; Herfert, Günter (Eds.): Suburbanisierung in Deutschland: Aktuelle Tendenzen. Opladen: Leske + Budrich: 43-56.

BAMF (Bundesamt für Migration und Flüchtlinge) (Ed.) 2016: Minas - Atlas über Migration, Integration und Asyl. 7. Auflage. Nürnberg.

Berlin-Institut für Bevölkerung und Entwicklung (Ed.) 2016: Im Osten auf Wanderschaft. Wie Umzüge die demografische Landkarte zwischen Rügen und Erzgebirge verändern. Berlin.

Berlin-Institut für Bevölkerung und Entwicklung (Ed.) 2011: Die Zukunft der Dörfer: Zwischen Stabilität und demografischem Niedergang. Berlin.

Böltken, Ferdinand; Bucher, Hansjörg; Janich, Helmut 1997: Wanderungsverflechtungen und Hintergründe räumlicher Mobilität in der Bundesrepublik seit 1990. In: Informationen zur Raumentwicklung 1/2: 35-50.

Bourne, Larry S. 1996: Reurbanization, Uneven Urban Development, and the Debate on New Urban Forms. In: Urban Geography 17,8: 690-713 [doi: 10.2747/02723638.17.8.690].

Brake, Klaus; Herfert, Günter (Eds.) 2012: Reurbanisierung: Materialität und Diskurs in Deutschland. Wiesbaden: VS Verlag für Sozialwissenschaften [doi: 10.1007/978-3531-94211-7].

Brake, Klaus; Urbanczyk, Rafael 2012: Reurbanisierung - Strukturierung einer begrifflichen Vielfalt. In: Brake, Klaus; Herfert, Günter (Eds.): Reurbanisierung: Materialität und Diskurs in Deutschland. Wiesbaden: VS Verlag für Sozialwissenschaften: 34-51 [doi: 10.1007/978-3-531-94211-7_3].

Bucher, Hansjörg; Kocks, Martina 1987: Die Suburbanisierung in der ersten Hälfte der 80er Jahre. In: Informationen zur Raumentwicklung 11/12: 689-707.

Bucher, Hans-Jörg; Schlömer, Claus 2012: Eine demographische Einordnung der ReUrbanisierung. In: Bundesinstitut für Bau-, Stadt- und Raumforschung (BBSR) im Bundesamt für Bauwesen und Raumordnung (Ed.): Die Attraktivität großer Städte: ökonomisch, demographisch, kulturell. Bonn: 66-72. 
Busch, Roland 2016: Inländische Wanderungen in Deutschland - wer gewinnt und wer verliert? In: Zeitschrift für Immobilienökonomie 2,2: 81-101 [doi: 10.1365/s41056-0160012-3].

Der Ministerpräsident des Landes Nordrhein-Westfalen - Landesplanungsbehörde 1979: Landesentwicklungsplan I/II „Raum- und Siedlungsstruktur". In: Ministerialblatt für das Land Nordrhein-Westfalen. Nr. 50 vom 22. Juni 1979: 1080-1114.

Gans, Paul 2000: Urban Population Change in Large Cities in Germany, 1980-94. In: Urban Studies 37,9: 1497-1512 [doi: 10.1080/00420980020080231].

Gans, Paul; Schlömer, Claus 2014: Phasen internationaler Migration und ihre Auswirkungen auf Raum- und Siedlungsentwicklung in Deutschland seit 1945. In: Gans, Paul (Ed.): Räumliche Auswirkungen der internationalen Migration. Forschungsberichte der ARL 3. Hannover: 127-161.

Gerber, Kim 2011: Räumliche Mobilität im Wandel: Wanderungen im Lebenslauf und ihre Auswirkungen auf die Stadtentwicklung in Nordrhein-Westfalen. Wiesbaden: VS Verlag für Sozialwissenschaften [doi: 10.1007/978-3-531-92909-5].

Glatter, Jan; Siedhoff, Mathias 2008: Reurbanisation: Inflationary Use of an Insufficiently Defined Term? Comments on the Definition of a Key Concept of Urban Geography, with Selected Findings for the City of Dresden. In: Die Erde 139,4: 289-308.

Haase, Annegret et al. 2010: Emergent spaces of reurbanisation: exploring the demographic dimension of inner-city residential change in a European setting. In: Population, Space and Place 16,5: 443-463 [doi: 10.1002/psp.603].

Häußermann, Hartmut; Läpple, Dieter; Siebel, Walter 2008: Stadtpolitik. Edition Suhrkamp 2512. Frankfurt am Main: Suhrkamp.

Hallenberg, Bernd 2002: Aktuelle Entwicklungen und Perspektiven der StadtUmland-Wanderung unter besonderer Berücksichtigung der Wohneigentumsbildung. In: vhw Forum Wohneigentum 3: 133-142.

Herfert, Günter 1998: Stadt-Umland-Wanderung in den 90er Jahren: Quantitative und qualitative Strukturen in den alten und neuen Ländern. In: Informationen zur Raumentwicklung 11/12: 763-776.

Herfert, Günter et al. 2010: Reurbanisierung in ostdeutschen Grossstädten: Regionale, städtische und Quartiersanalysen unter besonderer Berücksichtigung demographischer Prozesse. In: disP - The Planning Review 46,180: 24-35 [doi: 10.1080/02513625 .2010.10557061].

Herfert, Günter; Osterhage, Frank 2012: Wohnen in der Stadt: Gibt es eine Trendwende zur Reurbanisierung? Ein quantitativ-analytischer Ansatz. In: Brake, Klaus; Herfert, Günter (Eds.): Reurbanisierung: Materialität und Diskurs in Deutschland. Wiesbaden: VS Verlag für Sozialwissenschaften: 86-112 [doi: 10.1007/978-3-531-94211-7_6].

Hesse, Markus 2010: Reurbanisierung oder Metropolisierung? Entwicklungspfade, Kontexte, Interpretationsmuster zum aktuellen Wandel der Grossstadtregionen. In: disP - The Planning Review 46,180: 36-46 [doi: 10.1080/02513625.2010.10557062].

Hirschle, Michaela; Schürt, Alexander 2008: Suburbanisierung ... und kein Ende in Sicht? Intraregionale Wanderungen und Wohnungsmärkte. In: Informationen zur Raumentwicklung 3/4: 211-227.

Kabisch, Sigrun; Steinführer, Annett; Haase, Annegret 2012: Reurbanisierung aus soziodemographischer Perspektive: Haushalte und Quartierswandel in der inneren Stadt. In: Brake, Klaus; Herfert, Günter (Eds.): Reurbanisierung: Materialität und Diskurs in Deutschland. Wiesbaden: VS Verlag für Sozialwissenschaften: 113-129 [doi: 10.1007/978-3-531-94211-7_7]. 
Kanaroglou, Pavlos; Braun, Gerhard 1992: The pattern of counterurbanization in the Federal Republic of Germany 1977-85. In: Environment and Planning A 24,4: 481-496 [doi: 10.1068/a240481].

Kemper, Franz-Josef 2006: Internationale Wanderungen und ausländische Bevölkerung in Deutschland. In: Zeitschrift für Bevölkerungswissenschaft 31,3-4: 389-412.

Kemper, Franz-Josef 2003: Binnenwanderungen in Deutschland: Rückkehr alter Muster? In: Geographische Rundschau 55,6: 10-15.

Kemper, Franz-Josef 1999: Binnenwanderungen und Dekonzentration der Bevölkerung: Jüngere Entwicklungen in Deutschland. In: Schultz, Hans-Dietrich (Ed.): Quodlibet Geographicum: Einblicke in unsere Arbeit. Berliner Geographische Arbeiten 90. Berlin: 105-122.

Kemper, Franz-Josef 1985: Die Bedeutung des Lebenszyklus-Konzepts für die Analyse intraregionaler Wanderungen. In: Kemper, Franz-Josef; Laux, Hans-Dieter; Thieme, Günther (Eds.): Geographie als Sozialforschung: Beiträge zu ausgewählten Problemen kulturgeographischer Forschung. Colloquium Geographicum 18. Bonn: Dümmler: 180-212.

Kley, Stefanie 2011: Explaining the Stages of Migration within a Life-course Framework. In: European Sociological Review 27,4: 469-486 [doi: 10.1093/esr/jcq020].

Kley, Stefanie 2009: Migration im Lebensverlauf: Der Einfluss von Lebensbedingungen und Lebenslaufereignissen auf den Wohnortwechsel. Wiesbaden: VS Verlag für Sozialwissenschaften.

Köppen, Bernhard; Mai, Ralf; Schlömer, Claus 2007: Reurbanisierung in Ostdeutschland - möglicher Leittrend zukünftiger Stadtentwicklung? In: Geographische Zeitschrift 95,4: 211-230 [http://www.jstor.org/stable/27819129, 16.08.2018].

Kollenbroich, Britta; Teevs, Christian; Kaiser, Rosa 2016: Stadt, Land, Flucht: Wo die Deutschen leben wollen [http://www.spiegel.de/wirtschaft/soziales/wohnen-indeutschland-immer-mehr-menschen-zieht-es-aufs-land-a-1109484.html, 01.09.2017].

Kontuly, Thomas; Schön, Karl Peter 1994: Changing Western German Internal Migration Systems during the Second Half of the 1980s. In: Environment and Planning A 26,10: 1521-1543 [doi: 10.1068/a261521].

Kontuly, Thomas et al. 1997: Political Unification and Regional Consequences of German East-West Migration. In: International Journal of Population Geography 3,1: 31-47 [doi: 10.1002/(SICI)1099-1220(199703)3:1<31::AID-IJPG54>3.0.CO;2-G].

Korcz, Richard; Schlömer, Claus 2008: Perspektiven internationaler Wanderungen und demographische Heterogenisierung in den Regionen Deutschlands. In: Informationen zur Raumentwicklung 3/4: 153-169.

Mai, Ralf; Sch/ömer, Claus 2007: Erneute Landflucht? Wanderungen aus dem ländlichen Raum in die Agglomerationen. In: Zeitschrift für Bevölkerungswissenschaft 32,3-4: 713-742.

Milbert, Antonia 2017: Wie viel (Re-)Urbanisierung durchzieht das Land? BBSR-Analysen KOMPAKT 07/2017. Bonn.

Milbert, Antonia; Sturm, Gabriele 2016: Binnenwanderungen in Deutschland zwischen 1975 und 2013. In: Informationen zur Raumentwicklung 2: 121-144.

Ministerium für Inneres und Kommunales des Landes Nordrhein-Westfalen 2016: Bericht des Ministers für Inneres und Kommunales zum Tagesordnungspunkt "Immense Herausforderung steigender Flüchtlingszahlen für die Kommunen - Flüchtlingszahlen im Jahr 2015“ der Sitzung des Ausschusses für Kommunalpolitik am 22. Januar 2016. 
Münter, Angelika; Osterhage, Frank 2017: Der regionale Wohnungsmarkt der Stadt Aachen: grenzenlos oder begrenzt? ILS-TRENDS 1/17. Dortmund: ILS - Institut für Landes- und Stadtentwicklungsforschung.

Ochs, Birgit 2016: Wohnort-Trendwende: Jetzt geht es wieder raus aufs Land [http:// www.faz.net/aktuell/wirtschaft/immobilien/deutsche-landgebiete-erhalten-wieder-zuwachs-14430840.html, 01.09.2017].

Osterhage, Frank 2011: Von der Stadtflucht zur Renaissance der Städte? Empirische Ergebnisse und methodische Anmerkungen zur Untersuchung der Reurbanisierungsthese. In: Helbich, Marco; Deierling, Hannah; Zipf, Alexander (Eds.): Theorie und quantitative Methoden in der Geographie - Kolloquiumsbeiträge. Heidelberger Geographische Bausteine 19. Heidelberg: 23-31.

Parr, John B. 2012: The Spatial-Cycle Model (SCM) Revisited. In: Regional Studies 46,2: 217-228 [doi: 10.1080/00343404.2011.558895].

Rérat, Patrick 2012: The New Demographic Growth of Cities: The Case of Reurbanisation in Switzerland. In: Urban Studies 49,5: 1107-1125 [doi: 10.1177/0042098011408935].

Rossi, Peter H. 1955: Why Families Move: A Study in the Social Psychology of Urban Residential Mobility. Glencoe: The Free Press.

Sander, Nikola 2014: Internal Migration in Germany, 1995-2010: New Insights into EastWest Migration and Re-urbanisation. In: Comparative Population Studies 39,2: 217 246 [doi: 10.12765/CPoS-2014-04en].

Sch/ömer, Claus 2012: Zusammenhänge zwischen internationalen Wanderungen und Binnenwanderungen - die indirekten Folgen der Internationalisierung. In: Köppen, Bernhard et al. (Eds.): Internationalisierung: Die unterschätzte Komponente des demographischen Wandels in Deutschland? Schriftenreihe der DGD 5. Norderstedt: 4364.

Schlömer, Claus 2009: Binnenwanderungen in Deutschland zwischen Konsolidierung und neuen Paradigmen: Makroanalytische Untersuchungen zur Systematik von Wanderungsverflechtungen. Berichte 31. Bonn: BBSR.

Schlömer, Claus 2004: Binnenwanderungen seit der deutschen Einigung. In: Raumforschung und Raumordnung 62,2: 96-108 [doi: 10.1007/BF03184362].

Siedentop, Stefan 2008: Die Rückkehr der Städte? Zur Plausibilität der Reurbanisierungshypothese. In: Informationen zur Raumentwicklung 3/4: 193-210.

Siedentop, Stefan et al. 2003: Siedlungsstrukturelle Veränderungen im Umland der Agglomerationsräume. Forschungen 114. Bonn: BBSR.

Simons, Harald; Weiden, Lukas 2016: Schwarmverhalten, Reurbanisierung und Suburbanisierung. In: Informationen zur Raumentwicklung 3: 263-273.

Statistisches Bundesamt (Ed.) 2017: Wanderungen (Binnenwanderung, Außenwanderung, Gesamtwanderung) 2015: Qualitätsbericht. Wiesbaden.

van den Berg et al. 1982: Urban Europe. A Study of Growth and Decline. Urban Europe 1. Oxford et al.: Pergamon Press.

Vogelsang, Roland; Kontuly, Thomas 1986: Counterurbanisation in der Bundesrepublik Deutschland: ein Begriff zur Umschreibung gegenwärtiger regionaler Bevölkerungsveränderungen. In: Geographische Rundschau 38,9: 461-468.

Wagner, Michae/ 1989: Räumliche Mobilität im Lebensverlauf: eine empirische Untersuchung sozialer Bedingungen der Migration. Stuttgart: Enke. 
Worbs, Susanne et al. 2005: Räumliche Verteilung und Wohnsituation von Zuwanderern in Deutschland. In: Verbundpartner "Zuwanderer in der Stadt" (Eds.): Expertisen zum Projekt. Darmstadt: Schader-Stiftung: 13-72.

Frank Osterhage ( $₫)$. ILS - Research Intitute for Regional and Urban Development. Dortmund, Germany. E-mail: frank.osterhage@ils-research.de

URL: https://www.ils-forschung.de/index.php?lang=en\&s=osterhage\&sub= 


\section{Comparative Population Studies}

WWW.comparativepopulationstudies.de

ISSN: 1869-8980 (Print) - 1869-8999 (Internet)

\section{Published by}

Prof. Dr. Norbert F. Schneider

Federal Institute for Population Research D-65180 Wiesbaden / Germany

\section{(cc) BY-SA}

2018

\section{Managing Editor}

Dr. Katrin Schiefer

\section{Copy Editor}

Dr. Evelyn Grünheid

Dr. Katrin Schiefer

\section{Editorial Assistant}

Beatriz Feiler-Fuchs

Wiebke Hamann

\section{Layout \\ Beatriz Feiler-Fuchs \\ E-mail:cpos@bib.bund.de}

\section{Scientific Advisory Board}

Karsten Hank (Cologne)

Michaela Kreyenfeld (Berlin)

Marc Luy (Vienna)

Peter Preisendörfer (Mainz)

Nikola Sander (Wiesbaden)

Zsolt Spéder (Budapest)

Rainer Wehrhahn (Kiel)

\section{Board of Reviewers}

Martin Abraham (Erlangen)

Laura Bernardi (Lausanne)

Hansjörg Bucher (Bonn)

Claudia Diehl (Konstanz)

Andreas Diekmann (Zurich)

Gabriele Doblhammer-Reiter (Rostock)

Jürgen Dorbritz (Wiesbaden)

Anette Eva Fasang (Berlin)

E.-Jürgen Flöthmann (Bielefeld)

Alexia Fürnkranz-Prskawetz (Vienna)

Beat Fux (Salzburg)

Joshua Goldstein (Berkeley)

Sonja Haug (Regensburg)

Hill Kulu (Liverpool)

Aart C. Liefbroer (The Hague)

Kurt Lüscher (Konstanz)

Emma Lundholm (Umeå)

Nadja Milewski (Rostock)

Dimiter Philipov (Vienna)

Roland Rau (Rostock)

Tomáš Sobotka (Vienna)

Jeroen Spijker (Barcelona)

Olivier Thévenon (Paris)

Helga de Valk (Brussels)

Heike Trappe (Rostock)

Michael Wagner (Cologne) 